\title{
Black Coral.
}

\section{By Prof. Sydney J. Hickson, F.R.S., The University, Manchester.}

$\mathrm{I}^{\mathrm{N}}$ a short article by Prof. J. Stanley Gardiner published in Nature of December I5, I92 I (vol. I08, p. 505), attention was directed to the use of black coral by the natives of Java for making bracelets which are believed to act as a cure for rheumatism and to the widespread belief, "from Suez to the most distant parts of the Pacific," in the efficacy of certain magical powers of this substance. The use of black coral for this purpose is not only very widespread at the present day but has been prevalent also among both barbaric and civilised races from time immemorial. The $\dot{a}^{3} \nu \tau \iota \pi a \theta \theta^{\prime} s$ of the ancient Greeks was in all probability a kind of black coral, and was used as an antidote to the stings of scorpions and for other medical and magical purposes. According to some of the older writers the herb given by Mercury to Ulysses as a charm to protect him from Circe was a piece of Antipathes. Rumphius quotes Salmasius as having written in his notes on Solinus that Antipathes was used as a protection against sorcery. Pliny refers to it in his alphabetical list of stones. He says, Book XXXVII., Chapter 54, "Antipathes is black and not transparent : the mode of testing for it is by boiling it in milk, to which, if genuine, it imparts an odour (?) like that of myrrh." Dioscorides regarded Antipathes as a kind of black coral which was possessed of certain medical properties.

These and other references to the substance by ancient Greek and Roman authors do not, it is true, give us any certain clue as to the identity of their Antipathes, and it is only by indirect circumstantial evidence that the conclusion is arrived at that it was the axis of one of two or three kinds of marine flexible coral.

The definition of the word "corallium" as used in the time of Pliny may be derived from the comment he makes upon Gorgonia. "Gorgonia nihil aliud est quam curalium: nominis causa, quod in duritiam lapidis mutatur emollitum in mari; hanc fascinationibus resistere adfirmant."

There is no truth in the belief that corals are soft in the sea and become hard when exposed to the air, and we cannot, in modern times, accept the statement that they have the power of resisting fascinations; but it is reasonable to interpret this definition by Pliny to mean that to the Romans of his time coral was a marine substance with a soft cortex when fresh and that it was commonly believed to possess certain magical properties.

Pliny's milk test for Antipathes is interesting but unfortunately very obscure. The phrase he uses is "experimentum eius, ut coquatur in lacte : facit enim id murrae simile." But similar to myrrh in what respect? In odour, in colour, or in form? Solinus considers it to have been similar to myrrh in odour (Collect. v. 26), but other authors have interpreted Pliny to mean similar to myrrh in colour. I have recently applied this test to a piece of Antipathes in my possession and have found after prolonged boiling in milk there is a faint odour resembling that of heated myrrh, but the colour of neither the milk nor the coral seems to be in any way affected. For this reason I am inclined to believe, until my experiments on this subject are extended, that Pliny meant to say "similar in odour to myrrh."

Let us turn now to another fragmentary indication of the ancient use of black coral. The word "coral" is to be found in two texts of the English version of the Bible (Job xxviii. I8 and Ezekiel xxvii. I6). Prof. Peake has kindly informed me that Gesenius and other commentators consider that the Hebrew word "Ramoth" which is translated "coral" in the E.V. means "black coral," and that the word "Peninim" which is translated "rubies" in the E.V. really means "red coral." Thus Job xxviii. verse I8 should read: "No mention should be made of black coral or of pearls: for the price of wisdom is above red coral." I am not competent to form any definite opinion on the views of these commentators; but if they are right and black coral was known to the ancient Jews there may also be some explanation of a remarkable passage in the writings of Josephus.

In his book on the Antiquities of the Jews (i. 3. 6) Josephus relates that according to Berosus, the Chaldean, there is still some part of Noah's Ark in Armenia, and the natives carry off pieces of the bitumen (pitch ?) from it to make into amulets for averting mischief. We have in this passage reference to a substance like bitumen (i.e. black and flexible when heated) which was made into bracelets and believed to possess magical properties. Of course, it may nöt have been black coral at all, but if black coral accompanied by the beliefs in its efficacy against evils of many kinds was transported to distant parts of the world, as we know red coral was transported at that period, it would not be remarkable if it became associated with the Noah's Ark myth. It would be a matter of great interest if scholars learned in Jewish antiquities could throw some further light on the use of either black or red coral by the children of Israel in early times.

The making of amulets from the pitch of Noah's Ark, and their use for averting mischief, brings us back to the statement in the article in NATURE mentioned above that the natives of Java make bracelets of black coral for curing rheumatism. The most complete account of this superstition in the Malay Archipelago is to be found in Rumphius's "Amboinsch Kruidboek" (xii. p. 195), published in 1750, in the article on Corallium nigrum or Accarbaar itam. Rumphius says that the natives make bracelets of it by soaking it in cocoa-nut oil and bending it into the form required over a slow fire while smearing it all the time with oil. It is then polished with a rough leaf. Sometimes it is inlaid with gold or silver ornaments. It is supposed to confer on the wearer all kinds of blessings (zegeningen) and to protect him from sorcery. It is sometimes made into sceptres for the chiefs and is also made into a powder by grinding with a stone, mixed with water and drunk as a medicine. 
It would take too much space to give in detail the various diseases for which black coral was used as a remedy; but there is one point of difference between the account given by Rumphius of the use of the bracelets in his time and the account given by $\mathrm{Mr}$. Pownall in his letter quoted in Nature. Mr. Pownall says " the natives maintain that it must be used quite plain; and ornamentation of gold or silver renders them quite useless." Rumphius says that they ornament the inside of the bracelets with gold figures because they say, and "not without reason," that the coral must scratch the skin if it is to do any good. We may wonder if Rumphius smiled to himself when he wrote the words " niet zonder reden" in this sentence.

There were other kinds of Accarbaar or bastard corals which were known to the Malays in the time of Rumphius and used by them for medicinal purposes, but the Accarbaar itam or Corallium nigrum was regarded as the most important and was held in the highest esteem. Among these was the Accarbaar puti, which from the figure given by Rumphius was an Alcyonarian belonging to the family Isidæ and probably to the type genus Isis. This is of some special interest as the Mediterranean species of Isis was held in high esteem by the Mediterranean races in classical times, and was currently believed to represent the petrified hair of Isis. But that is another story, and one about which only the most fragmentary indications remain.

The task of identifying the various kinds of black coral mentioned by the ancient and later writers up to the end of the eighteenth century is extremely difficult, as detailed descriptions of the characters upon which the modern classification is based are almost entirely lacking. The substance was evidently black or brown in colour, it was capable of being bent or twisted when subjected to heat, and it was hard enough to be given a polished surface. Moreover, it may be presumed from various references that it was a product of the sea. It might have been, therefore, the Keratin axis of one of the Plexauridæ, of one of the Gorgonidæ or of one of the Antipatharia, or, finally, of Gerardia savalia.

The Accarbaar itam of Rumphius was probably a Plexaurid. The figure of the stript coral that Rumphius gives is not conclusive but quite consistent with this identification. In the description of the cœnenchym which covers the axis, when it is fresh, he uses the Dutch work Schorse, i.e. bark, whereas in the description of another Accarbaar which is almost certainly a Gorgonid he uses the word Korste, i.e. crust. In the description of a third Accarbaar which is obviously an Antipatharian he uses the word Slijm, i.e. slime. With such an accurate observer as Rumphius was, we may assume that the use of these different words for the cœnenchym signified a real difference in character between them. In the. Plexauridæ the cœnenchym is relatively thick, in the Gorgonidæ it is almost invariably much thinner, whereas in the Antipatharia it is usually little more than a soft and delicate film covering the axis. This identification of the Accarbaar itam of Rumphius as a Plexaurid is consistent with Prof. Gardiner's identification of the bracelets obtained by Mr. Pownall in Java as the axis of Plexaura.
Rumphius states that the Accarbaar itam is not identical with Pliny's Antipathes because it does not give the smell or colour of myrrh on boiling in milk. For other reasons than this, however, we may feel certain that the Antipathes of Pliny and the earlier writers was not a Plexaurid. The evidence seems to point to the conclusion that the black coral commonly used by the ancients was the form mentioned by Imperato (r599) as Savaglia and now known to science as Gerardia savalia. (Until quite recently Gerardia was considered to be an Antipatharian, but it has now been definitely placed in the order Zoanthidea.) The reason for believing that it was Gerardia is that this coral grows in the Mediterranean Sea, whilst the Plexauridæ do not, that it attains to great dimensions (a great specimen in the British Museum being two metres in height and spreading fan-wise to a width of over two metres) and the surface of the branches is smooth and devoid of spines. It is possible that in addition to the Gerardia the main stem of some of the species of Antipatharia that are found in the Mediterranean Sea may also have been used. Gansius in his "Historia Coralliorum" (1666) describes a species, Antipathes hirsutum, found in the Sardinian seas which is in length greater than the human stature. The axis of such a specimen if polished would be difficult to distinguish from that of Gerardia.

The difficulty of determining the black coral of the ancients, however, is due to the possibility that they may have imported it from the South, in which case Plexaurid or Gorgonid coral may also have come into use. Thus Pliny says in writing on coral, Nat. Hist. xxxii. I I, "Gignitur et in Rubro quidem mari sed nigrius item in Persico-vocatur Jace-laudatissimum (i.e. red coral) in gallico sinu circa Stoechades insulas," etc. This passage indicates that the most valuable kind of coral known to the Romans came from the Iles D'Hyères and other places in the Mediterranean Sea, but a black kind was also imported from the Red Sea and the Persian Gulf, in which seas the Corallium rubrum is not found.

Black coral was also known to the Moors in early times, and was very probably obtained by the fishermen engaged in the famous red-coral fishery off Marsa-al-Kharaz, the modern Bona or Bône on the coast of Algeria. The Arabic name for black coral was "yasz" or "yusz," a word which seems to have some resemblance to Pliny's " jace."

These few notes on the use of black coral in early times may seem to be very fragmentary and inconclusive, but they may be, perhaps, sufficient to create some interest in and to stimulate further investigation in a chapter of zoological mythology which has not yet been written. It is probable that classical and oriental research will reveal a great many more references to this substance than are recorded in these notes, and it may be expected that the excavations of the antiquaries will bring to our collections some specimens of black coral that were used in ancient times; but I think there is sufficient evidence to prove that the belief in the magical properties of black coral is not only widespread at the present day but also carries with it the sanction of a tradition which has been transmitted from the early days of our Western civilisation. 